\title{
A randomized, controlled trial to evaluate the effect of an anti-interleukin-9 monoclonal antibody in adults with uncontrolled asthma
}

Chad K Oh ${ }^{1,3}$, Richard Leigh ${ }^{2}$, Kimmie K McLaurin ${ }^{1}$, Keunpyo Kim ${ }^{1}$ Micki Hultquist ${ }^{* *}$ and Nestor A Molfino ${ }^{1,3}$

\begin{abstract}
Background: Preclinical studies suggest that interleukin-9 may be a central mediator in the development and maintenance of airway inflammation in asthma. The aim of this study was therefore to evaluate the effects of MEDI-528, an anti-interleukin-9 monoclonal antibody, in adults with confirmed uncontrolled moderate-to-severe asthma.

Methods: In this prospective double-blind, multicenter, parallel-group study, 329 subjects were randomized (1:1:1:1) to subcutaneous placebo or MEDI-528 $(30,100,300 \mathrm{mg})$ every 2 weeks for 24 weeks, in addition to their usual asthma medications. The primary endpoint was change in mean Asthma Control Questionnaire-6 (ACQ-6) score at week 13. Secondary endpoints included weighted asthma exacerbation rates and pre-bronchodilator forced expiratory volume in 1 second ( $\left(\mathrm{EVV}_{1}\right)$ at weeks 13 and 25, as well as Asthma Quality of Life Questionnaire scores at weeks 12 and 25 and the safety of MEDI-528 throughout the study period. The primary endpoint was analyzed using analysis of covariance.
\end{abstract}

Results: The study population ( $n=327$ ) was predominantly female (69\%) with a mean age of 43 years (range 18-65). The mean (SD) baseline ACQ-6 score for placebo $(n=82)$ and combined MEDI-528 $(n=245)$ was $2.8(0.7)$ and $2.8(0.8)$; $\mathrm{FEV}_{1} \%$ predicted was 70.7\% (15.9) and 71.5\% (16.7). Mean (SD) change from baseline to week 13 in ACQ-6 scores for placebo vs combined MEDI-528 groups was $-1.2(1.0)$ vs $-1.2(1.1)(p=0.86)$. Asthma exacerbation rates $(95 \% \mathrm{Cl})$ at week 25 for placebo vs MEDI-528 were $0.58(0.36-0.88)$ vs $0.49(0.37-0.64)$ exacerbations/subject/year $(p=0.52)$. No significant improvements in $\mathrm{FEV}_{1} \%$ predicted were observed between the placebo and MEDI-528 groups. Adverse events were comparable for placebo (82.9\%) and MEDI-528 groups (30 mg, 76.5\%; 100 mg, 81.9\%; 300 mg, 85.2\%). The most frequent were asthma (placebo vs MEDI-528, 30.5\% vs 33.5\%), upper respiratory tract infection ( $14.6 \%$ vs $17.1 \%)$, and headache (9.8\% vs 9.8\%).

Conclusions: The addition of MEDI-528 to existing asthma controller medications was not associated with any improvement in ACQ-6 scores, asthma exacerbation rates, or FEV , values, nor was it associated with any major safety concerns.

Trial registration: ClinicalTrials.gov: NCT00968669.

Keywords: Asthma, Anti-IL-9 monoclonal antibody, MEDI-528

\section{Background}

Asthma is a chronic inflammatory airway disease characterized by variable airflow limitation, airway hyperresponsiveness, mucus hypersecretion, and structural changes to the airways that include proliferation of smooth muscle [1]. Interleukin (IL)-9, a multifunctional cytokine produced

\footnotetext{
* Correspondence: hultquistm@medimmune.com

'Medlmmune, One Medlmmune Way, Gaithersburg, MD, USA

Full list of author information is available at the end of the article
}

by type $2 \mathrm{~T}$ helper cells (Th2), lymphocytes, and mast cells, is proposed to be a central mediator in the pathogenesis of asthma. Interest in IL-9 was first triggered by genetic linkage studies [2] and supported by the finding that expression of IL-9 and its associated receptor is higher in the airways of subjects with asthma compared with healthy controls $[3,4]$. Further evidence has come from in vitro studies showing that IL-9 enhances the growth and/or activity of a variety of cell types and pro-
Ciomed Central

(c) 2013 Oh et al.; licensee BioMed Central Ltd. This is an Open Access article distributed under the terms of the Creative Commons Attribution License (http://creativecommons.org/licenses/by/2.0), which permits unrestricted use, distribution, and reproduction in any medium, provided the original work is properly cited. 
inflammatory and pro-fibrotic mediators that are implicated in the pathogenesis of asthma [5]. IL-9 induced the release of Th2-associated chemokines in cultured human airway smooth muscle cells [6] and enhanced the stem cell factor-dependent growth of human mast cell progenitors, particularly those from children with asthma [7]. Another study reported that IL-9 upregulated mucin expression in human lung cells, suggesting that it is involved in the control of mucus secretion [8].

Preclinical studies in animal models of asthma support a contributing role for an IL-9 mast cell axis in the immunopathology of asthma [5]. In one study, anti-IL9 antibody treatment had a protective effect against airway remodeling in mouse models of airway inflammation, together with a concomitant reduction in the number and activation of mature mast cells [9]. Furthermore, impaired lung function related to airway remodeling was reversed by IL- 9 neutralization. Taken together, evidence from these and other experimental studies indicated that targeting IL-9 may offer a novel approach to the treatment of asthma.

MEDI-528 is a humanized immunoglobulin G1 monoclonal antibody that binds to IL-9 [10], and hence reduces the activity of a variety of cell types implicated in asthma pathogenesis [5]. Preliminary clinical studies in healthy adults and subjects with mild or mild-to-moderate asthma have demonstrated that MEDI-528 administered subcutaneously has linear pharmacokinetics and an acceptable safety profile with no reports of serious adverse events (SAEs) $[11,12]$. One study in subjects with mild asthma showed that MEDI-528 had no effect on pulmonary function or the use of rescue medication, although there were positive trends for improvement in asthma symptom scores and for a reduction in the number of asthma exacerbations [11]. Another study in a small number of subjects with mild-to-moderate asthma suggested that MEDI-528 may decrease sensitivity to exercise-induced bronchoconstriction that is dependent on mast cell degranulation [11]. We now report the results from a larger study (ClinicalTrials.gov, NCT00968669) that was designed to further investigate the potential clinical benefits of MEDI-528 in treating subjects with asthma. The primary objective of this study was to evaluate the effect of multiple dose subcutaneous administration of MEDI-528 on symptom control in adults with uncontrolled, moderate-to-severe, persistent asthma.

\section{Methods}

\section{Subjects}

Eligible subjects were aged 18-65 years with body mass index $18-35 \mathrm{~kg} / \mathrm{m}^{2}$ and a clinical diagnosis of asthma, confirmed by pre-bronchodilator forced expiratory volume in 1 second $\left(\mathrm{FEV}_{1}\right) \geq 40 \%$ predicted and post-bronchodilator $\mathrm{FEV}_{1}$ reversibility $\geq 12 \%$ and $\geq 200 \mathrm{~mL}$.
Subjects were required to have poor asthma symptom control [1], as demonstrated by an Asthma Control Questionnaire-6 (ACQ-6) score $\geq 1.5$ [13], daytime symptoms on $\geq 2$ days/week, night-time awakening $\geq 1$ night/week, rescue medication use on $\geq 2$ days/week, and $\geq 1$ asthma exacerbation in the past year. Subjects were either currently taking medium to high-dose inhaled corticosteroids (ICS) or were eligible to take them based on Expert Panel Report 3 guidelines, and were started on medium to high-dose ICS at the start of the run-in phase of the study [1]. Key exclusion criteria were the presence of other lung diseases, severe depression or history of suicidal behavior, tobacco smoking ( $\geq$ 10 pack-years), recent illness or infection, or clinically significant electrocardiogram (ECG) abnormalities. Treatment with any other biologic agent or immunosuppressive medication (apart from $\leq 10 \mathrm{mg} /$ day oral prednisone or equivalent, or inhaled or topical corticosteroids) was not allowed during the month prior to and throughout the study. Subjects were permitted to receive a short burst of systemic corticosteroid therapy or be hospitalized to control an asthma exacerbation.

All subjects provided written informed consent before participating in the study. The protocol was approved by an Independent Ethics Committee at each study center, and the study was conducted in accordance with International Conference on Harmonisation Guidance for Good Clinical Practice and the Declaration of Helsinki.

\section{Study design and randomization}

This phase $2 \mathrm{~b}$, randomized, double-blind, placebo-controlled, parallel group study was conducted at 53 sites in North America, Central America, South America, and Asia between October 2009 and November 2011. The study consisted of a 4-week screening period, a 13-week steroid stable treatment period, an 11-week steroid reduction treatment period, and a 22-week follow-up period (Figure 1). The ICS dosage was optimized and stabilized during the screening period, maintained unchanged throughout the steroid-stable treatment period, and was reduced in subjects with clinically stable asthma during the steroid-reduction treatment period. Subjects were seen at the clinic twice during the screening period (weeks -4 and -2 ), at two-weekly intervals during the treatment period (weeks 0 to 24) with an additional visit at week 13, and then at four-weekly intervals during the post-treatment follow-up period (weeks 25 to 46).

Subjects were randomized (1:1:1:1) using an interactive voice response system to receive placebo or one of three doses of MEDI-528 (30, 100, or $300 \mathrm{mg}$ ) subcutaneously every 2 weeks for 24 weeks (13 doses), in addition to their usual asthma medications. Because MEDI-528 and placebo are visually distinct, study medication was administered at the clinic by unblinded personnel who were 


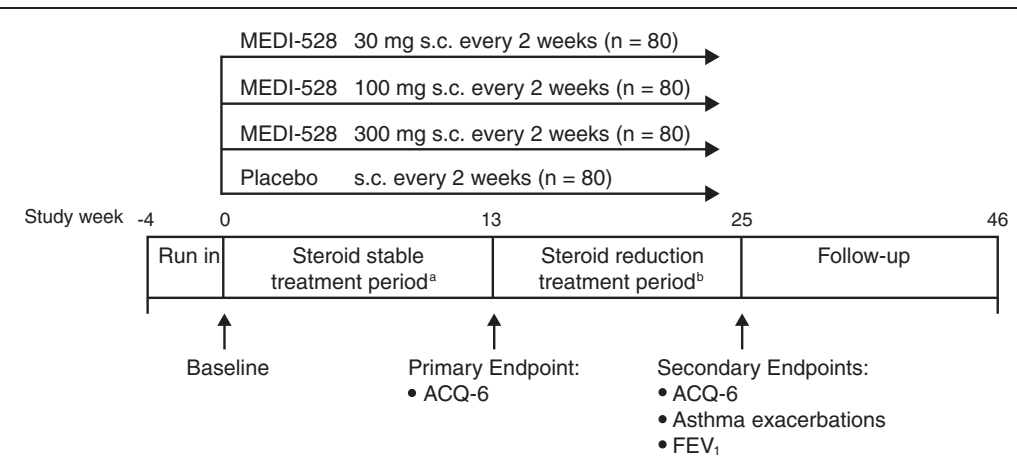

Figure 1 Study design. ${ }^{a}$ Inhaled corticosteroids at stable dose: fluticasone/salmeterol (500 $\mu \mathrm{g} / 50 \mu \mathrm{g}$ or $250 \mu \mathrm{g} / 50 \mu \mathrm{g}$ ) or budesonide/formoterol $(160 \mu \mathrm{g} / 4.5 \mu \mathrm{g})$. ${ }^{\text {b }}$ Subjects with clinically stable asthma could reduce their inhaled corticosteroid dose to: fluticasone/salmeterol $(250 \mu \mathrm{g} / 50 \mu \mathrm{g} \mathrm{or}$ $100 \mu \mathrm{g} / 50 \mu \mathrm{g})$ or budesonide/formoterol $(80 \mu \mathrm{g} / 4.5 \mu \mathrm{g})$. Abbreviations: ACQ-6, Asthma Control Questionnaire-6; FEV ${ }_{1}$, Forced expiratory volume in 1 second; s.c, Subcutaneous.

not otherwise involved in the study in order to maintain blinding.

Randomization was stratified by asthma status (atopic or non-atopic) and ICS dose (medium or high). High-dose ICS was defined as 1 puff twice a day of fluticasone/ salmeterol $(500 \mu \mathrm{g} / 50 \mu \mathrm{g})$ and medium dose ICS was defined as 1 puff twice a day fluticasone/sal meterol $(250 \mu \mathrm{g} / 50 \mu \mathrm{g})$ or 2 puffs twice a day budesonide/ formoterol $(160 \mu \mathrm{g} / 4.5 \mu \mathrm{g})$. Only subjects who were taking medium- to high-dose ICS at screening were enrolled. Subjects who were uncontrolled while receiving medium-dose ICS were enrolled to the medium-dose or high-dose ICS group at the study physician's discretion depending on their level of asthma control, and subjects receiving high-dose ICS were enrolled to the high-ICS group. Randomization of subjects with non-atopic asthma was restricted to ensure that a minimum of 160 subjects with atopic asthma were included in the study.

\section{Primary and secondary outcomes}

The primary efficacy outcome was change from baseline in mean ACQ-6 score at week 13 among individual MEDI-528 treatment groups and placebo. Secondary outcomes included change from baseline in mean ACQ-6 score at week 25, asthma exacerbation rates (week 25), pre-bronchodilator $\mathrm{FEV}_{1}$ (weeks 13 and 25), health-related quality of life (Asthma Quality of Life Questionnaire (Standardized version) [AQLQ(S)] scores; weeks 12 and 25), and the safety of MEDI-528 throughout the study period.

\section{Assessments}

\section{Clinical activity}

The ACQ-6 was completed at home on a weekly basis, using an electronic patient-reported outcome device. The occurrence of any asthma exacerbations during the study was recorded by the study physician at each clinic visit. Asthma exacerbation was defined as a progressive increase in asthma symptoms (cough, wheeze, chest tightness, and/or shortness of breath) with a reduction from baseline or best previous measurement of $\geq 20 \%$ in $\mathrm{FEV}_{1}$ or peak expiratory flow (PEF) rate that did not resolve after the initiation of rescue medication and resulted in a prescription for, or administration of, systemic corticosteroid burst therapy. An exacerbation was considered to be resolved when the subject's asthma symptoms had diminished, and PEF or $\mathrm{FEV}_{1}$ returned to $>80 \%$ of baseline for $\geq 7$ days after completion of systemic corticosteroid burst therapy. Pre-bronchodilator spirometry was conducted according to the American Thoracic Society/ European Respiratory Society guidelines [14]. All spirometry assessments for each subject were performed at the same time of day ( \pm 1 hour) and in the same manner. Between three and eight forced expiratory efforts were made at each session and the maximum $\mathrm{FEV}_{1}$ of the two best efforts was recorded.

\section{Health-related quality of life}

The AQLQ(S) was completed every 4 weeks at home using the electronic patient-reported outcome device.

\section{Safety profile}

Details of any adverse events (AEs) and SAEs were recorded. AEs were defined as any untoward medical occurrence that occurred after initiation of study medication. Blood and urine samples were collected at screening, prior to the first dose, at 4-weekly intervals during the treatment period, and 8-weekly intervals during the follow-up period for routine clinical laboratory evaluations. Vital signs (blood pressure, heart rate, temperature, and respiratory rate) were monitored at every clinic visit. A computerized 12-lead ECG was recorded. Blood samples were collected for determination of the presence of anti-drug antibodies (ADAs) using an enzyme-linked immunosorbent or electrochemiluminescent assay [12]. 


\section{Statistical methods}

Sample size calculations were based on an assumed change from baseline to week 13 in mean ACQ-6 score of -0.4 to -0.5 for placebo and -0.9 to -1.1 for the MEDI-528 groups, with a common standard deviation (SD) of 0.8 to $1.0[15,16]$. Sixty subjects in each treatment group would allow detection of a statistically significant difference between treatment groups with $58-99 \%$ power based on a 2-sided type I error of 0.05 and 0.10 . Assuming a drop-out rate of $20 \%$, it was planned to randomize 80 subjects into each treatment group.

The intent-to-treat (ITT) population was defined as all randomized subjects who received either placebo or MEDI-528. The safety population included all subjects who received either placebo or MEDI-528 and had safety data. Statistical analysis of clinical activity was based on a comparison of placebo with the individual MEDI-528 treatment groups for the ITT population.

Change from baseline (week 0) in mean ACQ-6 score at weeks 13 (primary endpoint) and 25 was analyzed using an analysis of covariance model. The model included the treatment group, atopic asthma status, geographic region, baseline eosinophil level, and mean ACQ score at baseline. Any missing ACQ-6 scores at weeks 13 and 25 were imputed using the last observation carried forward method. A sensitivity analysis was performed after excluding subjects with missing ACQ-6 scores at weeks 13 and 25 . The proportion of subjects with an improvement in mean ACQ- 6 score of $\geq 0.5$ at weeks 13 and 25 was compared between placebo and MEDI-528 using Fisher's exact test. Subgroup analyses were conducted on the primary efficacy outcome by atopic asthma status (atopic asthma, non-atopic asthma) and baseline use of
ICS (medium dose, high dose). A subgroup analysis was conducted on the primary efficacy outcome by peripheral blood eosinophil count $<0.3 \times 10^{3} / \mu \mathrm{L}$ or $\geq 0.3 \times 10^{3} / \mu \mathrm{L}$.

Weighted asthma exacerbation rate and the $95 \%$ confidence interval $(\mathrm{CI})$ were calculated as the total number of exacerbations/total duration of person-year followup. The weighted asthma exacerbation rate at week 25 was analyzed using a pair-wise Poisson regression. Change from baseline in pre-bronchodilator $\mathrm{FEV}_{1}$ at week 25 was compared between placebo and MEDI-528 using a pair-wise t-test. The proportion of subjects with an improvement in overall AQLQ(S) score of $\geq 0.5$ at weeks 12 and 25 was compared between placebo and MEDI-528 using Fisher's exact test. Safety variables were analyzed descriptively based on the safety population.

\section{Results}

\section{Subjects}

Of the 329 randomized subjects, 327 received either placebo or MEDI-528 and were included in the ITT and safety populations. Overall, $64 / 82(78.0 \%)$ of the placebo-treated and 207/245 (84.5\%) of the MEDI-528 treated subjects completed the study. The most common reason for discontinuation was withdrawal of consent (Figure 2).

Demographic characteristics were generally balanced between the groups (Table 1). The study population was predominantly female $(69 \%)$ with a mean age of 43.0 years (range 18-65). Most subjects (84.4\%) had atopic asthma and $50.3 \%$ had evidence of a peripheral blood eosinophilia (eosinophil count $\geq 0.3 \times 10^{3} / \mu \mathrm{L}$ ). Mean baseline ACQ-6 scores (2.8 for both placebo and combined MEDI-528 groups) indicated uncontrolled

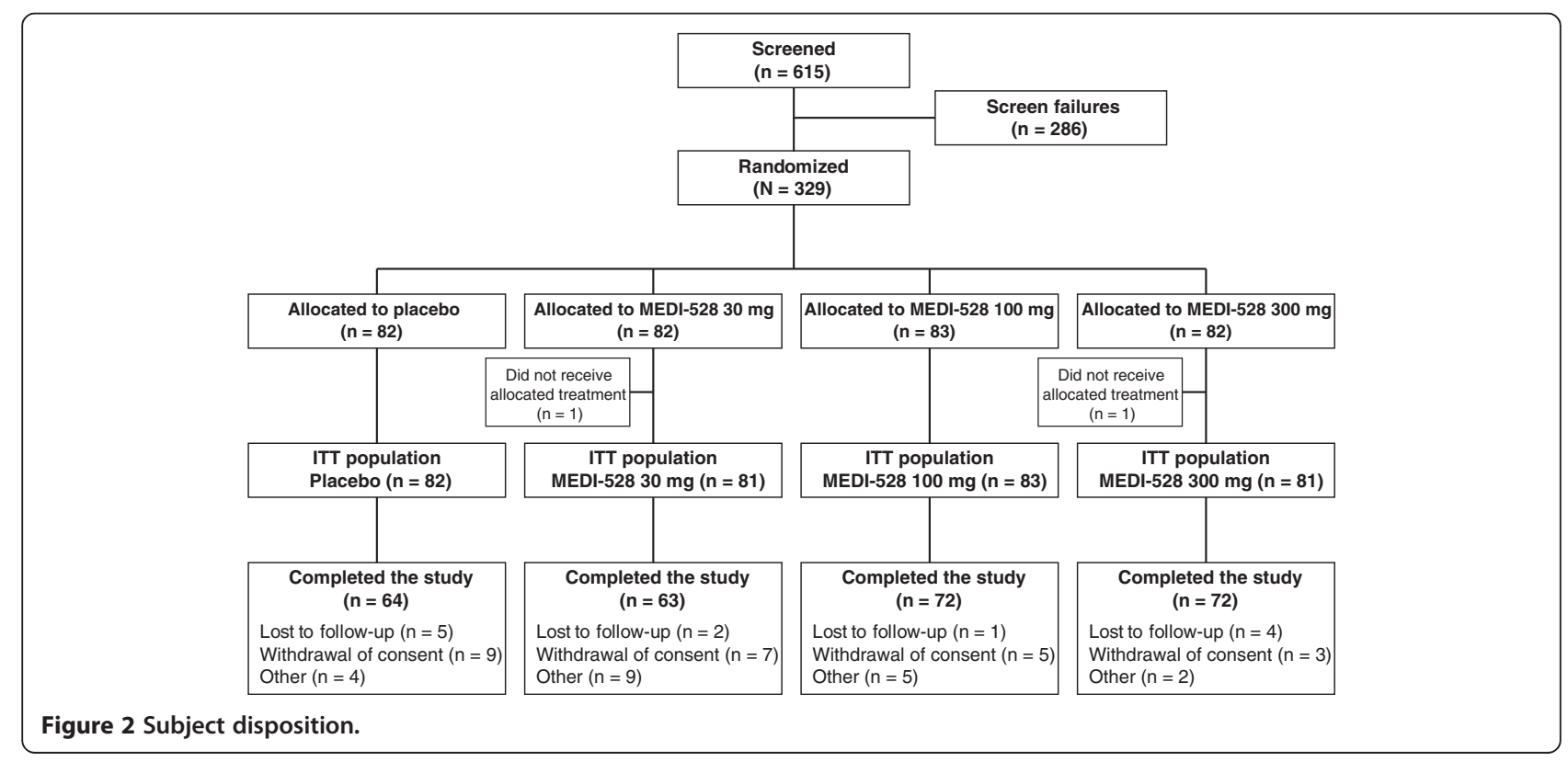


Table 1 Demographic and baseline asthma characteristics (ITT Population)

\begin{tabular}{|c|c|c|c|c|c|c|}
\hline \multirow[b]{2}{*}{ Variable } & \multirow[b]{2}{*}{$\begin{array}{l}\text { Placebo } \\
(n=82)\end{array}$} & \multicolumn{4}{|c|}{ MEDI-528 } & \multirow[b]{2}{*}{$\begin{array}{c}P \\
\text { value }^{\mathrm{a}}\end{array}$} \\
\hline & & $\begin{array}{c}30 \mathrm{mg} \\
(\mathrm{n}=81)\end{array}$ & $\begin{array}{l}100 \mathrm{mg} \\
(\mathrm{n}=83)\end{array}$ & $\begin{array}{l}300 \mathrm{mg} \\
(\mathrm{n}=81)\end{array}$ & $\begin{array}{c}\text { Combined } \\
(n=245)\end{array}$ & \\
\hline Age, years, mean (SD) & $43.6(11.6)$ & $41.8(11.1)$ & $45.1(11.6)$ & $41.5(12.3)$ & $42.8(11.7)$ & 0.16 \\
\hline Male, n (\%) & $29(35.4)$ & $26(32.1)$ & $21(25.3)$ & $26(32.1)$ & $73(29.8)$ & 0.56 \\
\hline Race, n (\%) & & & & & & 0.62 \\
\hline White & $42(51.2)$ & $34(42.0)$ & $33(39.8)$ & $40(49.4)$ & $107(43.7)$ & \\
\hline Asian & $18(22.0)$ & $17(21.0)$ & $25(30.1)$ & $18(22.2)$ & $60(24.5)$ & \\
\hline American Indian or Alaskan Native & $5(6.1)$ & $8(9.9)$ & $8(9.6)$ & $4(4.9)$ & $20(8.2)$ & \\
\hline Black or African American & $2(2.4)$ & $3(3.7)$ & $4(4.8)$ & $5(6.2)$ & $12(4.9)$ & \\
\hline Mixed race & $1(1.2)$ & $0(0.0)$ & $0(0.0)$ & $2(2.5)$ & $2(0.8)$ & \\
\hline Other & $14(17.1)$ & $19(23.5)$ & $13(15.7)$ & $12(14.8)$ & $44(18.0)$ & \\
\hline $\mathrm{BMl}, \mathrm{kg} / \mathrm{m}^{2}$, mean $(\mathrm{SD})$ & $27.6(4.3)$ & $27.1(4.4)$ & $26.9(4.3)$ & $27.2(4.4)$ & $27.1(4.3)$ & 0.79 \\
\hline$\overline{\mathrm{FEV}} \mathrm{V}_{1}(\mathrm{~L})$ & $2.21(0.74)$ & $2.22(0.71)$ & $2.05(0.62)$ & $2.27(0.66)^{b}$ & $2.18(0.67)^{c}$ & 0.19 \\
\hline $\mathrm{FEV}_{1}, \%$ predicted & $70.7(15.9)$ & $71.8(17.6)$ & $70.6(16.6)$ & $72.2(15.9)^{b}$ & $71.5(16.7)^{c}$ & 0.90 \\
\hline FVC, \% predicted & $83.9(14.6)$ & $86.1(16.7)$ & $84.8(14.3)$ & $84.7(14.8)$ & $85.2(15.2)$ & 0.83 \\
\hline$\overline{\mathrm{FEV}}{ }_{1} / \mathrm{FVC}$ & $68.0(10.4)$ & $67.6(10.8)$ & $67.0(11.3)$ & $69.4(10.8)^{b}$ & $68.0(11.0)^{c}$ & 0.57 \\
\hline $\mathrm{FEV}_{1}$ reversibility, \%, mean (SD) & $25.2(13.8)^{\mathrm{b}}$ & $23.9(10.2)^{d}$ & $25.6(15.3)^{d}$ & $21.8(11.1)^{\mathrm{e}}$ & $23.8(12.5)^{f}$ & 0.25 \\
\hline Atopic asthma, n (\%) & $70(85.4)$ & $69(85.2)$ & $69(83.1)$ & $68(84.0)$ & $206(84.1)$ & 0.98 \\
\hline Number of exacerbations requiring oral steroids in past year, $\mathrm{n}(\%)^{9}$ & & & & & & 0.33 \\
\hline 0 & $2(2.4)$ & $5(6.2)$ & $1(1.2)$ & $4(4.9)$ & $10(4.1)$ & \\
\hline 1 & $45(54.9)$ & $47(58.0)$ & $42(51.2)$ & $39(48.1)$ & $128(52.5)$ & \\
\hline 2 & $16(19.5)$ & $12(14.8)$ & $16(19.5)$ & $12(14.8)$ & $40(16.4)$ & \\
\hline 3 & $5(6.1)$ & $5(6.2)$ & $10(12.2)$ & $15(18.5)$ & $30(12.3)$ & \\
\hline $4+$ & $14(17.1)$ & $12(14.8)$ & $13(15.7)$ & $11(13.6)$ & $36(14.7)$ & \\
\hline ICS use, $\mathrm{n}(\%)$ & & & & & & 0.81 \\
\hline Medium dose & $43(52.4)$ & $38(46.9)$ & $38(45.8)$ & $41(50.6)$ & $117(47.8)$ & \\
\hline High dose & $39(47.6)$ & $43(53.1)$ & $45(54.2)$ & $40(49.4)$ & $128(52.2)$ & \\
\hline Rescue medication use, puffs per day, mean (SD) & $4.3(4.0)$ & $4.9(5.6)$ & $4.5(4.5)$ & $5.9(7.3)$ & $5.1(5.9)$ & 0.25 \\
\hline Mean ACQ-6 score, mean (SD) & $2.8(0.7)$ & $2.7(0.9)$ & $2.8(0.7)$ & $2.9(0.9)$ & $2.8(0.8)$ & 0.62 \\
\hline Overall AQLQ(S) score, mean (SD) & $3.6(0.8)^{d}$ & $3.8(1.1)^{\mathrm{h}}$ & $3.8(0.9)^{i}$ & $3.8(0.9)^{h}$ & $3.8(0.9)^{j}$ & 0.60 \\
\hline Eosinophil count $\geq 0.3 \times 10^{3} / \mu \mathrm{L}, \mathrm{n}(\%)$ & $44(53.7)$ & $38(47.5)^{b}$ & $43(51.8)$ & $39(48.1)$ & $120(49.2)^{c}$ & 0.84 \\
\hline Eosinophil count $\left(10^{3} / \mu \mathrm{L}\right)$ & & & & & & 0.47 \\
\hline Mean & 0.40 & $0.34^{\mathrm{b}}$ & 0.40 & 0.35 & $0.36^{c}$ & \\
\hline Median & 0.31 & $0.28^{\mathrm{b}}$ & 0.37 & 0.29 & $0.29^{c}$ & \\
\hline Basophil count $\left(10^{3} / \mu \mathrm{L}\right)$ & & & & & & 0.05 \\
\hline Mean & 0.03 & $0.03^{b}$ & 0.03 & 0.03 & $0.03^{c}$ & \\
\hline Median & 0.03 & $0.03^{\mathrm{b}}$ & 0.02 & 0.03 & $0.02^{c}$ & \\
\hline
\end{tabular}

Abbreviations: ACQ-6 Asthma Control Questionnaire, AQLQ Asthma Quality of Life Questionnaire, BMI Body mass index, FEV ${ }_{1}$ Forced expiratory volume in 1 second, FVC Forced vital capacity, ICS Inhaled corticosteroids, ITT Intent-to-treat.

${ }^{\text {aP }}$ value for differences among groups (placebo and MEDI-528 groups) by analysis of variance for continuous variables and the chi-square test for categorical variables.

${ }^{b} n=80 ;{ }^{c} n=244 ;{ }^{d} n=79 ;{ }^{e} n=78 ;{ }^{f} n=236 ;{ }^{9}$ One value is missing in the MEDI-528 100 mg group; ${ }^{h} n=76 ;{ }^{i} n=81 ;{ }^{j} n=233$.

asthma, although 4 subjects (placebo, $\mathrm{n}=1 ; 30 \mathrm{mg}$ MEDI$528, \mathrm{n}=3$ ) had a mean ACQ-6 score $<1.5$ suggesting that their asthma was more controlled. Almost all subjects had experienced $\geq 1$ exacerbation requiring oral steroids in the past year (placebo 80/82, 97.6\%; MEDI-528 234/244, 95.9\%). At baseline, an average of 2.06 exacerbations/ subject required oral steroids during the previous year. Subjects in the placebo group appeared to have less severe asthma than those in the MEDI-528 groups, according to the proportion taking high-dose ICS ( $47.6 \%$ vs $52.2 \%$ ) and rescue medication use (mean number of puffs per day 4.3 vs 5.1 ), although there were no statistically significant 
differences between placebo and any of the three MEDI528 groups.

\section{Clinical activity Mean ACQ-6 score}

The primary outcome measure analyzed using an analysis of covariance model, change from baseline to week 13 in mean ACQ scores, was not significantly different between the placebo and the individual MEDI-528 groups $(\mathrm{p}=0.80)$. Improvements in mean ACQ-6 score occurred in all groups at weeks 13 and 25, with little difference between placebo and the individual MEDI-528 treatment groups (Figure 3). Clinically relevant improvements of $\geq$ 0.5 in mean ACQ-6 score occurred in similar proportions of placebo and combined MEDI-528 subjects at week $13(64 / 82$ [78.0\%] vs 184/245 [75.1\%], $\mathrm{p}=0.66)$ and week $25(59 / 82$ [72.0\%] vs 194/245 [79.2\%], $\mathrm{p}=0.22)$. In the individual MEDI-528 groups, a clinically relevant improvement was seen in the following proportions of subjects at week 13: $30 \mathrm{mg}$, 54/81 (66.7\%); $100 \mathrm{mg}, 66 / 83$ (79.5\%); and $300 \mathrm{mg}$, 64/81 (79.0\%); and at week 25: $30 \mathrm{mg}, 61 / 81$ (75.3\%); $100 \mathrm{mg}, 67 / 83$ (80.7\%); and $300 \mathrm{mg}, 66 / 81$ (81.5\%).

Differences between placebo and the combined MEDI528 groups were not significantly different when analyzed by atopic or non-atopic asthma, baseline medium- or high-dose ICS use, or peripheral blood eosinophil count $<$ 0.3 or $\geq 0.3 \times 10^{3} / \mu \mathrm{L}$ (Table 2). In addition, there was no difference between the steroid-stable and steroid reduction phases with regard to the effect of ICS and systemic steroids (data not shown).

\section{Asthma exacerbation rate}

At week 25, the weighted asthma exacerbation rate (exacerbations/subject/year, 95\% CI) for the placebo group was 0.58 (0.36-0.88) compared with $0.49(0.37-0.64)$ in the combined MEDI-528 groups $(\mathrm{p}=0.52)$. Results were similar for the individual MEDI-528 dose groups (Figure 4); weighted asthma exacerbation rates $(95 \% \mathrm{CI})$ at week 25 were $0.64(0.40-0.96)(\mathrm{p}=0.76)$ for $30 \mathrm{mg}$, $0.28(0.14-0.50)(\mathrm{p}=0.05)$ for $100 \mathrm{mg}$, and $0.58(0.36-$ $0.88)(\mathrm{p}=1.00)$ for $300 \mathrm{mg}$.

\section{Pre-bronchodilator FEV}

Mean increase from baseline in pre-bronchodilator $\mathrm{FEV}_{1}$ was similar between the placebo and MEDI-528 groups at weeks 13 and 25 (Figure 5). The $\mathrm{FEV}_{1} \%$ predicted mean (SD) change from baseline at week 25 for placebo vs the combined MEDI-528 groups was $1.44 \%$ (11.08) vs $1.12 \%(9.81)(\mathrm{p}=0.82)$; mean (SD) change in $\mathrm{FEV}_{1}$ absolute values were $0.04 \mathrm{~L}(0.37)$ vs $0.03 \mathrm{~L}(0.30)(\mathrm{p}=0.82)$. In the individual MEDI-528 dose groups, mean (SD) change from baseline at week 25 was $-0.01 \mathrm{~L}(0.32)(\mathrm{p}=0.41)$ for $30 \mathrm{mg}, 0.06 \mathrm{~L}(0.30)(\mathrm{p}=0.85)$ for $100 \mathrm{mg}$, and $0.05 \mathrm{~L}$ $(0.29)(\mathrm{p}=0.97)$ for $300 \mathrm{mg}$.

\section{Health-related quality of life}

A clinically relevant improvement of $\geq 0.5$ in overall AQ $\mathrm{LQ}(\mathrm{S})$ score was seen in similar proportions of placebo and MEDI-528 subjects at week $12(53 / 69,76.8 \%$ vs $144 /$ $207,69.6 \% ; \mathrm{p}=0.21)$ and week $25(50 / 62,80.6 \%$ vs $136 /$ $182,74.7 \% ; \mathrm{p}=0.57)$.

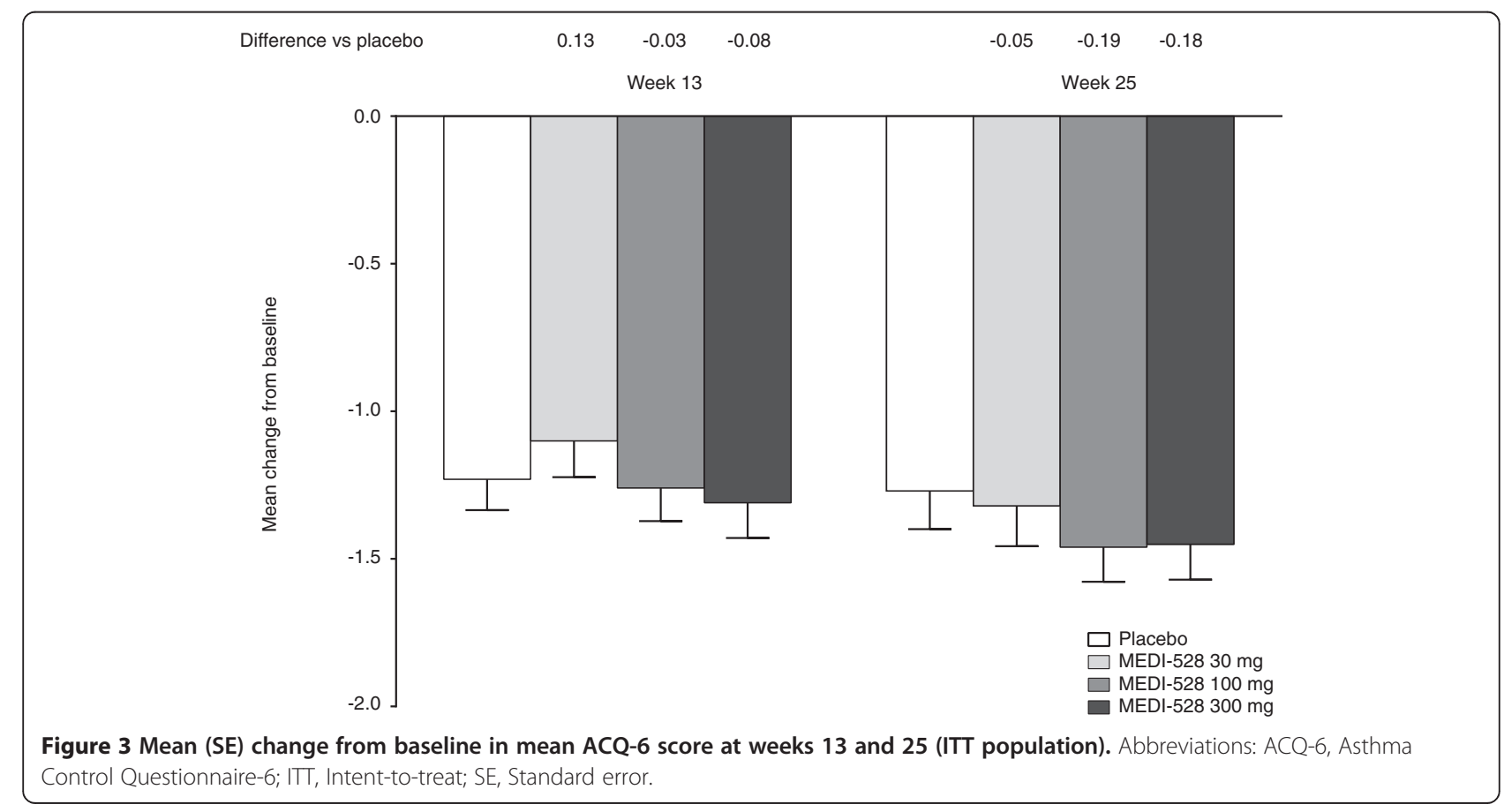


Table 2 ACQ score change from baseline to week 13 (ITT population)

\begin{tabular}{|c|c|c|c|c|c|}
\hline \multirow{2}{*}{ Variable } & \multicolumn{2}{|c|}{ Placebo } & \multicolumn{2}{|c|}{ Combined MEDI-528 } & \multirow{2}{*}{$\begin{array}{c}\mathrm{P} \\
\text { Value }\end{array}$} \\
\hline & $n$ & Mean (SD) & n & Mean (SD) & \\
\hline All subjects $^{a}$ & 82 & $-1.23(0.95)$ & 245 & $-1.22(1.07)$ & 0.86 \\
\hline \multicolumn{6}{|l|}{ Asthma type ${ }^{a}$} \\
\hline Atopic & 70 & $-1.28(0.97)$ & 206 & $-1.19(1.04)$ & 0.55 \\
\hline Non-atopic & 12 & $-0.94(0.82)$ & 39 & $-1.42(1.18)$ & 0.41 \\
\hline \multicolumn{6}{|l|}{ ICS use ${ }^{a}$} \\
\hline Medium dose & 43 & $-1.21(0.97)$ & 117 & $-1.17(1.02)$ & 0.55 \\
\hline High dose & 39 & $-1.26(0.94)$ & 128 & $-1.28(1.11)$ & 0.77 \\
\hline \multicolumn{6}{|l|}{ Eosinophil count $^{a}$} \\
\hline$\geq 0.3 \times 10^{3} / \mu \mathrm{L}$ & 44 & $-1.39(0.95)$ & 120 & $-1.17(1.01)$ & 0.14 \\
\hline$<0.3 \times 10^{3} / \mu \mathrm{L}$ & 38 & $-1.04(0.92)$ & 124 & $-1.26(1.09)$ & 0.22 \\
\hline All subjects without imputation & 67 & $-1.30(0.94)$ & 208 & $-1.28(1.10)$ & 0.75 \\
\hline
\end{tabular}

Abbreviations: ACQ Asthma Control Questionnaire, ICS Inhaled corticosteroid.

${ }^{a}$ Missing mean ACQ score at Week 13 was imputed using the last observation carried forward method.

${ }^{\mathrm{b}} \mathrm{P}$-values are calculated using an analysis of covariance with treatment and baseline value as covariates.

\section{Safety}

The proportion of subjects who reported at least one AE was similar between the placebo $(68 / 82,82.9 \%)$ and MEDI-528 (30 mg: 62/81, 76.5\%; 100 mg: 68/83, 81.9\%; 300 mg: 69/81, 85.2\%) groups. The most frequent AEs in the combined MEDI-528 groups were asthma, upper respiratory tract infection, and headache (Table 3). Most AEs were mild or moderate in severity. One subject in the MEDI-528 $100 \mathrm{mg}$ group had a mild hypersensitivity reaction on the day of dosing that was considered possibly related to study medication and resolved the following day.
SAEs were reported by 4 (4.9\%) and 15 (6.1\%) subjects in the placebo and combined MEDI-528 groups, respectively (Table 4). Two SAEs (pneumonia and asthma) in one subject who received $30 \mathrm{mg}$ MEDI-528 were considered to be possibly related to study medication. Six subjects discontinued the study due to AEs: one placebo (rash); two $30 \mathrm{mg}$ MEDI-528 (ischemic stroke, headache); one $100 \mathrm{mg}$ MEDI-528 (musculoskeletal pain and pain in extremity); and two $300 \mathrm{mg}$ MEDI-528 (headache, bladder transitional cell carcinoma). Three of the AEs that resulted in discontinuation were considered likely to be related

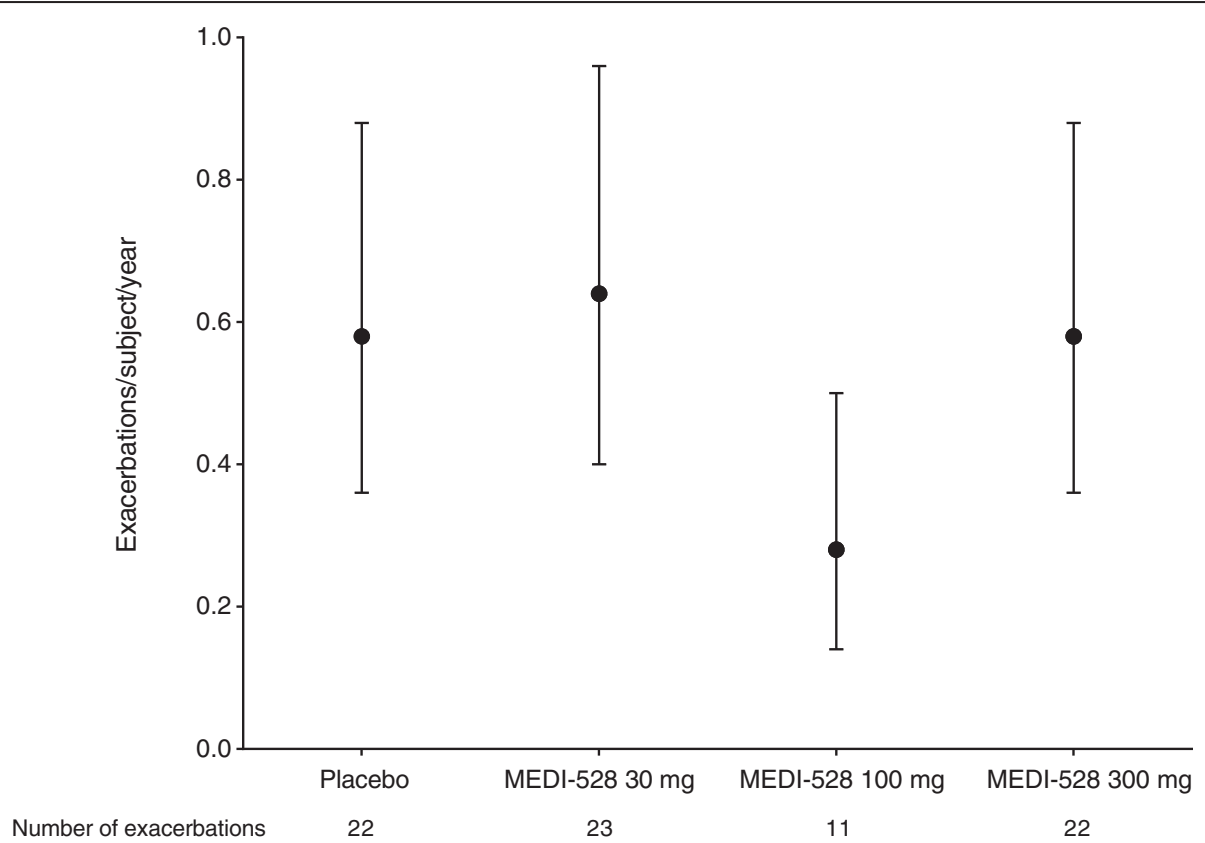

Figure 4 Weighted rate of asthma exacerbation $(95 \% \mathrm{Cl})$ at week 25 (ITT population). Abbreviation: ITT, Intent-to-treat. 


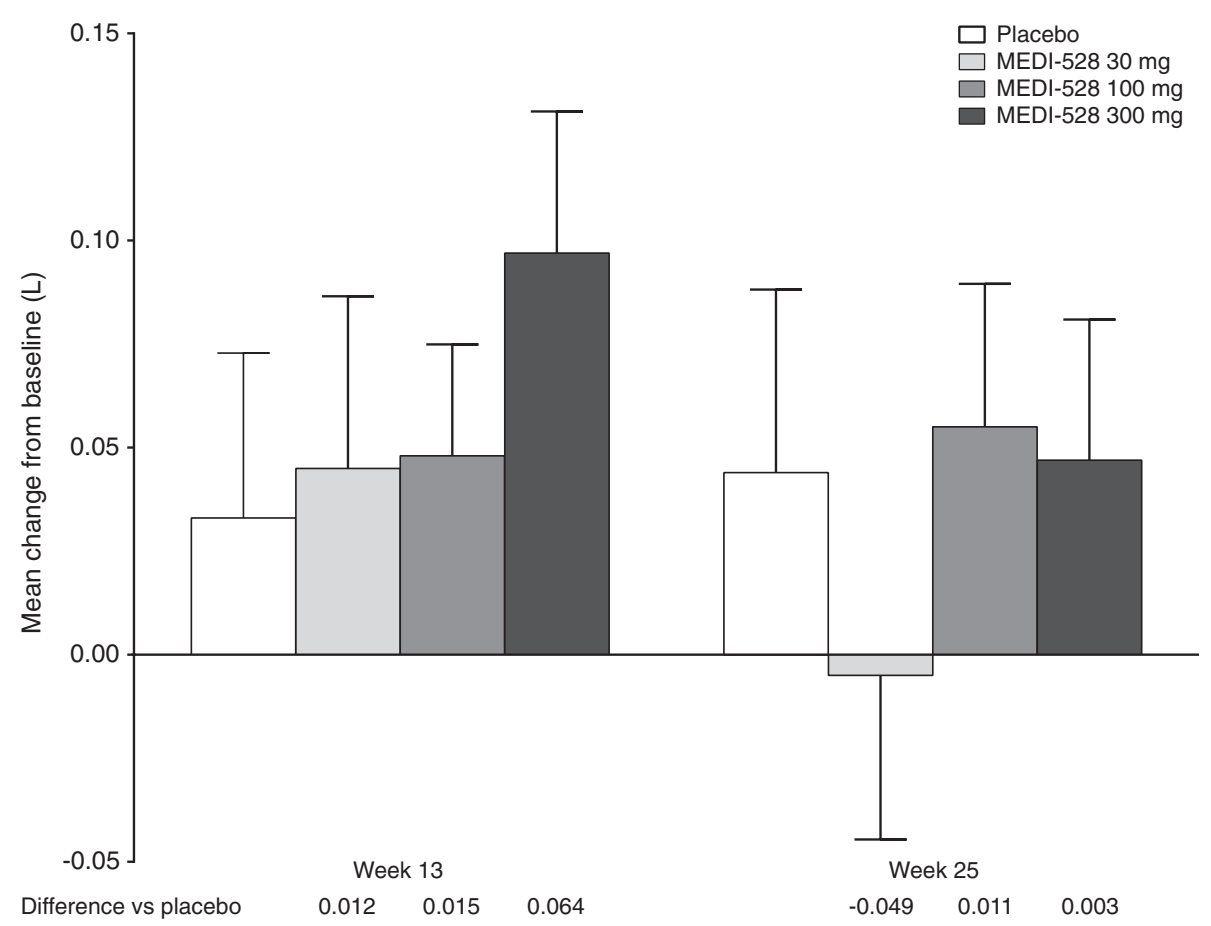

Figure 5 Mean (SE) change from baseline in pre-bronchodilator FEV1 at week $s 13$ and 25 (ITT population). Abbreviations: FEV 1 , Forced expiratory volume in 1 second; ITT, Intent-to-treat; SE, Standard error.

to study medication (100 mg, musculoskeletal pain and pain in extremity; $300 \mathrm{mg}$, headache).

No clinically relevant changes occurred in clinical laboratory values, vital signs, or ECGs.

ADAs occurred in $4 / 82$ subjects $(4.9 \%)$ in the placebo group and $22 / 245$ subjects $(9.0 \%)$ in the MEDI-528 groups (30 mg: 15/81, 18.5\%; 100 mg: 4/83, 4.8\%; 300 mg: 3/81, $3.7 \%$ ). ADAs were detected prior to day 0 in 1 subject in the placebo group and 14 subjects in the MEDI-528 group.

\section{Discussion}

This is the largest double-blind, placebo-controlled, doseranging study performed to date to determine whether an anti-IL-9 monoclonal antibody has any clinical benefits in subjects with poorly controlled, moderate-to-severe asthma. The results indicate that adding MEDI-528 to existing controller medications was not associated with any major safety concerns, but failed to achieve a clinically important effect on mean ACQ-6 scores at 13 weeks or on asthma exacerbation rates, lung function, or asthmarelated quality of life at the pre-specified time points. However, this study was powered to detect a change in the primary study endpoint of mean ACQ-6 score from baseline to week 13, thus statistical results for the secondary endpoints must be viewed in this context.

Data from preclinical studies provide strong evidence that an IL-9 mast cell axis regulates airway inflammation, mucus production, airway hyperresponsiveness, and subepithelial fibrosis, with increased IL-9 expression in the airways in humans with asthma [5]. For example, both Th9 and Th17 are involved in asthma pathogenesis and produce IL-9 [17]. Kim et al. demonstrated in Balb/c mice that cellular infiltration related to chronic airway inflammation and remodeling can be reduced by an antiIL-9 antibody. In addition, the number of Th9 cells, Th17 cells, mast cells, eosinophils, and neutrophils in the airway were reduced; the synthesis and secretion of cytokines was inhibited; and IgE synthesis in B cells was reduced [18]. These reported observations support our hypothesis that targeting IL-9 via an anti-IL-9 mAb would be an effective treatment for patients with poorly controlled asthma. Despite convincing in vitro and animal model data, there have been very few studies in humans examining IL-9 involvement in asthma.

In a previous small study in subjects with mild asthma, fewer subjects experienced $\geq 1$ asthma exacerbation in the combined MEDI-528 group (1/27) compared with the placebo group $(2 / 9 ; \mathrm{p}=0.15)$. The subject in the MEDI528 group who experienced an exacerbation received the lowest dose $(0.3 \mathrm{mg} / \mathrm{kg})$, which indicated that it was not due to a dose effect. These results suggested a potential improvement in asthma exacerbation rates in subjects with mild asthma [11]. However, in the current study, no significant differences in the asthma exacerbation rate occurred between placebo and MEDI-528 in adults with uncontrolled moderate-to-severe persistent asthma. 
Table 3 Adverse events that occurred in $\geq 2 \%$ of the combined MEDI-528 group (safety population)

\begin{tabular}{|c|c|c|c|c|c|}
\hline \multirow[b]{2}{*}{ Adverse event, $n(\%)$ of subjects } & \multirow[b]{2}{*}{$\begin{array}{l}\text { Placebo } \\
(n=82)\end{array}$} & \multicolumn{4}{|c|}{ MEDI-528 } \\
\hline & & $\begin{array}{c}30 \mathrm{mg} \\
(\mathrm{n}=81)\end{array}$ & $\begin{array}{l}100 \mathrm{mg} \\
(\mathrm{n}=83)\end{array}$ & $\begin{array}{l}300 \mathrm{mg} \\
(\mathrm{n}=81)\end{array}$ & $\begin{array}{c}\text { Combined } \\
(n=245)\end{array}$ \\
\hline Asthma & $25(30.5)$ & $30(37.0)$ & $21(25.3)$ & $31(38.3)$ & $82(33.5)$ \\
\hline Upper respiratory tract infection & $12(14.6)$ & $6(7.4)$ & $16(19.3)$ & $20(24.7)$ & $42(17.1)$ \\
\hline Headache & $8(9.8)$ & $13(16.0)$ & $5(6.0)$ & $6(7.4)$ & $24(9.8)$ \\
\hline Nasopharyngitis & $12(14.6)$ & $11(13.6)$ & $5(6.0)$ & $7(8.6)$ & $23(9.4)$ \\
\hline Sinusitis & $4(4.9)$ & $10(12.3)$ & $4(4.8)$ & $6(7.4)$ & $20(8.2)$ \\
\hline Influenza & $6(7.3)$ & $10(12.3)$ & $5(6.0)$ & $2(2.5)$ & $17(6.9)$ \\
\hline Urinary tract infection & $6(7.3)$ & $7(8.6)$ & $7(8.4)$ & $2(2.5)$ & $16(6.5)$ \\
\hline Pharyngitis & $2(2.4)$ & $4(4.9)$ & $8(9.6)$ & $4(4.9)$ & $16(6.5)$ \\
\hline Bronchitis & $8(9.8)$ & $4(4.9)$ & $2(2.4)$ & $5(6.2)$ & $11(4.5)$ \\
\hline Injection site erythema & $2(2.4)$ & $1(1.2)$ & $4(4.8)$ & $5(6.2)$ & $10(4.1)$ \\
\hline Allergic rhinitis & $7(8.5)$ & $5(6.2)$ & $1(1.2)$ & $3(3.7)$ & $9(3.7)$ \\
\hline Gastroenteritis & $3(3.7)$ & $2(2.5)$ & $5(6.0)$ & $2(2.5)$ & $9(3.7)$ \\
\hline Diarrhea & $2(2.4)$ & $3(3.7)$ & $3(3.6)$ & $3(3.7)$ & $9(3.7)$ \\
\hline Rhinitis & $5(6.1)$ & $3(3.7)$ & $3(3.6)$ & $2(2.5)$ & $8(3.3)$ \\
\hline Back pain & $2(2.4)$ & $3(3.7)$ & $3(3.6)$ & $2(2.5)$ & $8(3.3)$ \\
\hline Pneumonia & $0(0.0)$ & $5(6.2)$ & $0(0.0)$ & $3(3.7)$ & $8(3.3)$ \\
\hline Dizziness & $5(6.1)$ & $2(2.5)$ & $5(6.0)$ & $0(0.0)$ & $7(2.9)$ \\
\hline Injection site pain & $5(6.1)$ & $1(1.2)$ & $4(4.8)$ & $2(2.5)$ & $7(2.9)$ \\
\hline Rash & $3(3.7)$ & $2(2.5)$ & $1(1.2)$ & $4(4.9)$ & $7(2.9)$ \\
\hline Acute sinusitis & $2(2.4)$ & $3(3.7)$ & $2(2.4)$ & $2(2.5)$ & $7(2.9)$ \\
\hline Hypertension & $2(2.4)$ & $4(4.9)$ & $3(3.6)$ & $0(0.0)$ & $7(2.9)$ \\
\hline Pain in extremity & $2(2.4)$ & $1(1.2)$ & $3(3.6)$ & $3(3.7)$ & $7(2.9)$ \\
\hline Cough & $0(0.0)$ & $2(2.5)$ & $2(2.4)$ & $3(3.7)$ & $7(2.9)$ \\
\hline Oropharyngeal pain & $0(0.0)$ & $2(2.5)$ & $3(3.6)$ & $2(2.5)$ & $7(2.9)$ \\
\hline Pyrexia & $0(0.0)$ & $0(0.0)$ & $4(4.8)$ & $3(3.7)$ & $7(2.9)$ \\
\hline Migraine & $1(1.2)$ & $4(4.9)$ & $1(1.2)$ & $1(1.2)$ & $6(2.4)$ \\
\hline Pruritus & $1(1.2)$ & $1(1.2)$ & $2(2.4)$ & $3(3.7)$ & $6(2.4)$ \\
\hline Toothache & $1(1.2)$ & $2(2.5)$ & $4(4.8)$ & $0(0.0)$ & $6(2.4)$ \\
\hline Nasal congestion & $0(0.0)$ & $2(2.5)$ & $3(3.6)$ & $1(1.2)$ & $6(2.4)$ \\
\hline Pharyngotonsillitis & $0(0.0)$ & $5(6.2)$ & $0(0.0)$ & $1(1.2)$ & $6(2.4)$ \\
\hline Bacterial upper respiratory tract infection & $0(0.0)$ & $2(2.5)$ & $2(2.4)$ & $2(2.5)$ & $6(2.4)$ \\
\hline Asthenia & $2(2.4)$ & $3(3.7)$ & $1(1.2)$ & $1(1.2)$ & $5(2.0)$ \\
\hline Malaise & $1(1.2)$ & $0(0.0)$ & $3(3.6)$ & $2(2.5)$ & $5(2.0)$ \\
\hline Dyspepsia & $0(0.0)$ & $3(3.7)$ & $1(1.2)$ & $1(1.2)$ & $5(2.0)$ \\
\hline Musculoskeletal pain & $0(0.0)$ & $1(1.2)$ & $4(4.8)$ & $0(0.0)$ & $5(2.0)$ \\
\hline Bacterial pharyngitis & $0(0.0)$ & $2(2.5)$ & $1(1.2)$ & $2(2.5)$ & $5(2.0)$ \\
\hline
\end{tabular}

Likewise, the mean increase from baseline in prebronchodilator $\mathrm{FEV}_{1}$ was similar between the MEDI528 and placebo groups, which is consistent with the earlier study where $\mathrm{FEV}_{1}$ was essentially unchanged and short-acting beta agonist use was comparable among groups [11]. Studies with other monoclonal antibodies, including omalizumab [19] and mepolizumab [20], also reported modest, if any, improvements in $\mathrm{FEV}_{1}$.
Although the study did not meet its primary endpoint, all groups, including placebo, demonstrated improvements in mean ACQ-6 score at 13 weeks. The placebo response has been well described in asthma studies and various explanations have been proposed. For example, Wise et al. reported that the placebo effect on asthma symptoms could be augmented by an optimistic message from the physician that enhanced the subject's expectation of 
Table 4 Serious adverse events by treatment group (safety population)

\begin{tabular}{|c|c|c|c|c|c|}
\hline \multirow[b]{2}{*}{$\begin{array}{l}\text { Serious adverse event, } \\
\text { n (\%) of subjects }\end{array}$} & \multirow[b]{2}{*}{$\begin{array}{l}\text { Placebo } \\
(\mathrm{n}=82)\end{array}$} & \multicolumn{4}{|c|}{ MEDI-528 } \\
\hline & & $\begin{array}{l}30 \mathrm{mg} \\
(\mathrm{n}=81)\end{array}$ & $\begin{array}{l}100 \mathrm{mg} \\
(\mathrm{n}=83)\end{array}$ & $\begin{array}{l}300 \mathrm{mg} \\
(\mathrm{n}=81)\end{array}$ & $\begin{array}{c}\text { Combined } \\
(n=245)\end{array}$ \\
\hline Asthma & $0(0.0)$ & $6(7.4)$ & $1(1.2)$ & $2(2.5)$ & $9(3.7)$ \\
\hline Pneumonia & $0(0.0)$ & $3(3.7)$ & $0(0.0)$ & $0(0.0)$ & $3(1.2)$ \\
\hline Food allergy & $0(0.0)$ & $1(1.2)$ & $0(0.0)$ & $0(0.0)$ & $1(0.4)$ \\
\hline Bronchitis & $0(0.0)$ & $1(1.2)$ & $0(0.0)$ & $0(0.0)$ & $1(0.4)$ \\
\hline Lobar pneumonia & $0(0.0)$ & $0(0.0)$ & $1(1.2)$ & $0(0.0)$ & $1(0.4)$ \\
\hline Limb traumatic amputation & $0(0.0)$ & $1(1.2)$ & $0(0.0)$ & $0(0.0)$ & $1(0.4)$ \\
\hline Thoracic vertebral fracture & $0(0.0)$ & $0(0.0)$ & $1(1.2)$ & $0(0.0)$ & $1(0.4)$ \\
\hline Muscle spasms & $0(0.0)$ & $0(0.0)$ & $1(1.2)$ & $0(0.0)$ & $1(0.4)$ \\
\hline Uterine leiomyoma & $0(0.0)$ & $0(0.0)$ & $1(1.2)$ & $0(0.0)$ & $1(0.4)$ \\
\hline Complicated migraine & $0(0.0)$ & $1(1.2)$ & $0(0.0)$ & $0(0.0)$ & $1(0.4)$ \\
\hline Ischemic stroke & $0(0.0)$ & $1(1.2)$ & $0(0.0)$ & $0(0.0)$ & $1(0.4)$ \\
\hline$\underline{\text { Vaginal hemorrhage }}$ & $0(0.0)$ & $0(0.0)$ & $1(1.2)$ & $0(0.0)$ & $1(0.4)$ \\
\hline Pancreatitis & $1(1.2)$ & $0(0.0)$ & $0(0.0)$ & $0(0.0)$ & $0(0.0)$ \\
\hline Cholelithiasis & $1(1.2)$ & $0(0.0)$ & $0(0.0)$ & $0(0.0)$ & $0(0.0)$ \\
\hline Hydrocholecystis & $1(1.2)$ & $0(0.0)$ & $0(0.0)$ & $0(0.0)$ & $0(0.0)$ \\
\hline Appendicitis & $1(1.2)$ & $0(0.0)$ & $0(0.0)$ & $0(0.0)$ & $0(0.0)$ \\
\hline Nephrolithiasis & $1(1.2)$ & $0(0.0)$ & $0(0.0)$ & $0(0.0)$ & $0(0.0)$ \\
\hline
\end{tabular}

benefit from the drug [21]. Similarly, a large placebo response was observed in two pivotal studies of omalizumab and was explained by improved compliance with ICS treatment and/or intensive medical input [22].

It is becoming increasingly apparent that asthma is a heterogeneous disease, and that identification of potential subgroups or individual subject characteristics is likely to be key in delivering optimal response with therapeutics such as MEDI-528 that target specific immunological mechanisms. Subgroup analyses of the mean ACQ-6 score results provided no evidence that MEDI-528 may be effective in subjects with atopic asthma, peripheral blood eosinophilia, or in those taking moderate or high doses of ICS at entry to the study. Interpretation of these results should take into account the small numbers of subjects in some subgroups.

The heterogeneous nature of asthma makes it difficult for a targeted therapy with monoclonal antibodies such as MEDI-528 to show significant beneficial effects in a non-selected asthma population. Identification of biological markers may be of great help in determining more accurate asthma diagnosis and severity, predicting treatment response, or monitoring of disease control. Corren et al. showed that lebrikizumab increased $\mathrm{FEV}_{1}$ and reduced exacerbations in the high Th2 subgroup vs placebo [23]. Unfortunately, a pharmacodynamic marker for the IL-9 pathway has not been identified and IL-9 levels couldn't be measured in blood or sputum in this study. Furthermore, subgroup analyses of the primary endpoint in pre-specified subpopulations, stratified by atopic status or medium- vs high-dose ICS at screening, and other pre-specified subpopulations based on $\mathrm{FEV}_{1}$, ACQ score, reversibility, and blood eosinophilia at randomization did not identify a subpopulation with improved efficacy over placebo.

Overall, the safety profile of MEDI-528 was similar to earlier clinical studies [11,12] and no new safety concerns were identified. ADAs were detected in the placebo and all three MEDI-528 treatment groups. None of these events were considered to be serious, but it is unclear why ADAs were detected in the placebo group or in some subjects prior to administration of MEDI-528. Our ADA assays may nonspecifically detect cross-reacting antigen or other epitopes; however, it is not uncommon for subjects to develop antibodies against a biologic agent [24].

\section{Conclusions}

This study was designed to further evaluate the clinical effects of MEDI-528, an anti-IL-9 antibody, in light of the inconclusive results obtained in previous small studies. In this large study, we clearly demonstrated that adding MEDI-528 to existing controller medications was not associated with an improvement in ACQ-6 score, asthma exacerbation rate, $\mathrm{FEV}_{1}$, health-related quality of life, or any major safety concerns.

\section{Abbreviations}

ACQ-6: Asthma control questionnaire-6; ADA: Anti-drug antibody; AE: Adverse event; AQLQ(S): Asthma quality of life questionnaire (Standardized version); Cl: Confidence interval; ECG: Electrocardiogram; 
$\mathrm{FEV}_{1}$ : Forced expiratory volume in 1 second; ICS: Inhaled corticosteroids; IL: Interleukin; ITT: Intent-to-treat; PEF: Peak expiratory flow; SAE: Serious adverse event; SD: Standard deviation; Th2: T helper cells.

\section{Competing interests}

Chad Oh and Nestor Molfino were employed by Medlmmune during the conduct of the study and owned stock in AstraZeneca. Micki Hultquist, Kimmie McLaurin, and Keunpyo Kim are employees of Medlmmune and own stock in AstraZeneca. Richard Leigh has received research funding from Medlmmune, payable to the University of Calgary, for conducting this and other clinical studies over the past 3 years.

\section{Authors' contributions}

CKO participated in design and coordination of the study. RL was a principal investigator for the study. KKM participated in the design of the study and interpretation of results. KK participated in the design of the study and performed the statistical analysis. MH participated in study design and interpretation of results. NAM conceived the study and participated in its design and coordination. All authors have been involved in drafting the manuscript or revising it critically for important intellectual content, read, and approved the final manuscript.

\section{Acknowledgements}

The authors thank all subjects who consented to participate in this study, the study coordinators who facilitated the conduct of the study, and the following principal investigators.

Argentina: F Colodenco, J Maspero, L Nannini, A Stok, A Tolcachier, A Yanez. Brazil: E Fiss, C Fritscher, J Hetzel, E Pizzichini, R Stelmach. Canada: J Hebert, M Fitzgerald, R Olivenstein, I Mayers, A Cheema, W Yang. Colombia: A Casas, D Severiche, F Serrano, R Contreras, A Orozco. Costa Rica: T Mitchell. Panama: L Noriega. Peru: A Matsuno, C Villaran, J Portugal, O Cubas. Philippines: T Aquino, T Atienza, R Samoro. Taiwan: C-C Wang. USA: A Nayak, H Kaiser, J Winder, T Casale, J Corren, R Nathan, M White, D Dvorin, E Kerwin, J Matz, I Melamed, J Diaz, B Collins, B Chipps, C Chappel, L Mansfield, J Zwetchkenbaum, E Meltzer, S Pollard, N Kao.

We acknowledge Jennifer Stewart, MSc, (QXV Communications, Macclesfield, UK) for medical writing support, which was funded by Medlmmune; Diana Swanson, PhD, (Medlmmune) for document management and medical writing support, and Lourdes Briz (Medlmmune) for editorial support. The study sponsor, Medlmmune, was involved in the study design; collection, analysis, and interpretation of data; provided funding for writing support; and approved the decision to submit the manuscript for publication.

\section{Author details}

${ }^{1}$ Medlmmune, One Medlmmune Way, Gaithersburg, MD, USA. ${ }^{2}$ Department of Medicine, University of Calgary, Calgary, Alberta, Canada. ${ }^{3}$ Currently at KaloBios Pharmaceuticals, Inc, South San Francisco, CA, USA.

Received: 15 May 2013 Accepted: 5 September 2013

Published: 19 September 2013

\section{References}

1. National Heart, Lung, and Blood Institute: National Asthma Education and Prevention Program: Guidelines for the diagnosis and management of asthma: expert panel report 3, NIH Publication No. 07-4051. Bethesda, MD: National Institutes of Health; 2007.

2. Nicolaides NC, Holroyd KJ, Ewart SL, Eleff SM, Kiser MB, Dragwa CR, Sullivan CD, Grasso L, Zhang LY, Messler CJ, Zhou T, Kleeberger SR, Buetow KH Levitt RC: Interleukin 9: a candidate gene for asthma. Proc Natl Acad Sci USA 1997, 94:13175-13180

3. Longphre M, Li D, Gallup M, Drori E, Ordonez CL, Redman T, Wenzel S, Bice $D E$, Fahy JV, Basbaum C: Allergen-induced IL-9 directly stimulates mucin transcription in respiratory epithelial cells. J Clin Invest 1999, 104:1375-1382.

4. Shimbara A, Christodoulopoulos P, Soussi-Gounni A, Olivenstein R, Nakamura Y, Levitt RC, Nicolaides NC, Holroyd KJ, Tsicopoulos A, Lafitte JJ, Wallaert B, Hamid QA: IL-9 and its receptor in allergic and nonallergic lung disease: increased expression in asthma. J Allergy Clin Immunol 2000, 105:108-115.
5. Oh CK, Raible D, Geba GP, Molfino NA: Biology of the interleukin-9 pathway and its therapeutic potential for the treatment of asthma. Inflamm Allergy Drug Targets 2011, 10:180-186.

6. Gounni AS, Hamid Q, Rahman SM, Hoeck J, Yang J, Shan L: IL-9-mediated induction of eotaxin1/CCL11 in human airway smooth muscle cells. J Immunol 2004, 173:2771-2779.

7. Matsuzawa S, Sakashita K, Kinoshita T, Ito S, Yamashita T, Koike K: IL-9 enhances the growth of human mast cell progenitors under stimulation with stem cell factor. J Immunol 2003, 170:3461-3467.

8. Louahed J, Toda M, Jen J, Hamid Q, Renauld JC, Levitt RC, Nicolaides NC: Interleukin-9 upregulates mucus expression in the airways. Am J Respir Cell Mol Biol 2000, 22:649-656.

9. Kearley J, Erjefalt JS, Andersson C, Benjamin E, Jones CP, Robichaud A, Pegorier S, Brewah Y, Burwell TJ, Bjermer L, Kiener PA, Kolbeck R, Lloyd CM, Coyle AJ, Humbles AA: IL-9 governs allergen-induced mast cell numbers in the lung and chronic remodeling of the airways. Am J Respir Crit Care Med 2011, 183:865-875.

10. Humbles AA, Reed JL, Parker J, Kiener PA, Molfino NA, Kolbeck R, Coyle AJ: Monoclonal antibody therapy directed against interleukin-9: MEDI-528. In New drugs and targets for asthma and COPD. Edited by Hansel TT, Barnes PJ. Basel: Karger; 2010:137-140.

11. Parker JM, Oh CK, LaForce C, Miller SD, Pearlman DS, Le C, Robbie GJ, White WI, White B, Molfino NA: Safety profile and clinical activity of multiple subcutaneous doses of MEDI-528, a humanized anti-interleukin9 monoclonal antibody, in two randomized phase 2a studies in subjects with asthma. BMC Pulm Med 2011, 11:14.

12. White B, Leon F, White W, Robbie G: Two first-in-human, open-label, phase I dose-escalation safety trials of MEDI-528, a monoclonal antibody against interleukin-9, in healthy adult volunteers. Clin Ther 2009, 31:728-740.

13. Juniper EF, O'Byrne PM, Guyatt GH, Ferrie PJ, King DR: Development and validation of a questionnaire to measure asthma control. Eur Respir J 1999, 14:902-907.

14. Miller MR, Hankinson J, Brusasco V, Burgos F, Casaburi R, Coates A, Crapo R, Enright P, van der Grinten CP, Gustafsson P, Jensen R, Johnson DC, MacIntyre N, McKay R, Navajas D, Pedersen OF, Pellegrino R, Viegi G, Wanger J: Standardisation of spirometry. Eur Respir J 2005, 26:319-338.

15. Giraud $V$, Rogeaux $Y$, Dusser D: Asthma control following initial inhaled corticosteroid monotherapy in mild to moderate asthma: a 4- to 8-week observational study. Respiration 2006, 73:617-622.

16. Molimard M, Martinat Y, Rogeaux Y, Moyse D, Pello JY, Giraud V: Improvement of asthma control with beclomethasone extrafine aerosol compared to fluticasone and budesonide. Respir Med 2005, 99:770-778.

17. Stassen M, Schmitt E, Bopp T: From interleukin-9 to T helper 9 cells. Ann N Y Acad Sci 2012, 1247:56-68.

18. Kim MS, Cho KA, Cho YJ, Woo SY: Effects of interleukin-9 blockade on chronic airway inflammation in murine asthma models. Allergy Asthma Immunol Res 2013, 5:197-206.

19. Rodrigo GJ, Neffen H, Catro-Rodriguez JA: Efficacy and safety of subcutaneous omalizumab vs placebo as add-on therapy to corticosteroids for children and adults with asthma. Chest 2011, 139:28-35.

20. Pavord ID, Korn S, Howarth P, Bleecker ER, Buhl R, Keene ON, Ortega H, Chanez P: Mepolizumab for severe eosinophilic asthma (DREAM): a multicentre, double-blind, placebo-controlled trial. Lancet 2012, 380:651-659.

21. Wise RA, Bartlett SJ, Brown ED, Castro M, Cohen R, Holbrook JT, Irvin CG, Rand CS, Sockrider MM, Sugar EA: Randomized trial of the effect of drug presentation on asthma outcomes: the American Lung Association Asthma Clinical Research Centers. J Allergy Clin Immunol 2009, 124:436-438.

22. Bousquet J, Wenzel S, Holgate S, Lumry W, Freeman P, Fox H: Predicting response to omalizumab, an anti-lgE antibody, in patients with allergic asthma. Chest 2004, 125:1378-1386.

23. Corren J, Lemanske RF, Hanania NA, Korenblat PE, Parsey MV, Arron JR, Harris JM, Scheerens H, Wu LC, Su Z, Mosesova S, Eisner MD, Bohen SP, Matthews JG: Lebrikizumab treatment in adults with asthma. N Engl J Med 2011, 365:1088-1098.

24. Jones TD, Crompton L, Carr FJ, Baker MP: Deimmunization of monoclonal antibodies. Methods Mol Biol 2009, 525:405-423.

doi:10.1186/1465-9921-14-93

Cite this article as: Oh et al.: A randomized, controlled trial to evaluate the effect of an anti-interleukin-9 monoclonal antibody in adults with uncontrolled asthma. Respiratory Research 2013 14:93. 